\title{
MEMBANGUN KEMANDIRIAN BELAJAR SISWA MELALUI PEMBELAJARAN MATEMATIKA REALISTIK
}

\author{
Oleh: \\ 1) Saleh Haji, ${ }^{2)}$ M. Ilham Abdullah \\ ${ }^{1,2)}$ Program Pasca Sarjana (S2) Pendidikan Matematika FKIP Universitas Bengkulu \\ ${ }^{1}$ salehhaji25@gmail.com, ${ }^{2}$ ilhamabdullah418@gmail.com
}

\begin{abstract}
ABSTRAK
Tujuan penelitian ini adalah untuk mengetahui pencapaian dan peningkatan kemandirian belajar matematik siswa melalui pembelajaran matematika realistik. Metode penelitian yang digunakan adalah kuasi eksperimen dengan non-equivalent control group design Hasil penelitian sebagai berikut. pembelajaran matematika realistik lebih efektif dalam pencapaian dan peningkatan kemandirian belajar siswa dibandingkan pembelajaran konvensional. Perbedaan pencapaian dan peningkatan kemandirian belajar siswa pada kedua kelompok pembelajaran signifikan. Besarnya pencapaian kemandirian belajar matematik siswa kelompok pembelajaran matematika realistik dan siswa kelompok pembelajaran konvensional, masing-masing sebesar 176,85 dan 172,96. Sementara itu, besarnya peningkatan kemandirian belajar matematik siswa kelompok pembelajaran matematika realistik adalah 0,1 dibandingkan dengan pembelajaran konvensional.
\end{abstract}

Kata Kunci : Kemandirian belajar, Pembelajaran matematika realistik.

\begin{abstract}
The Purpose of this study is to determine the achievement and improvement of self regulated learning student through realistics mathematics learning. This study use a quasi-experimental design by the non-equivalent control group. The results are realistics mathematics learning more effectively in the achievement and improvement of self regulated learning student is compared conventional learning. Differences achievement and improvement in both groups is significant. The magnitude of the achievement of self regulated learning student is taught through realistics mathematics learning is 176.85 , while self regulated learning student is taught through conventional learning is 172.96 . While, the magnitude of the increase in self regulated learning student is taught realistic mathematics learning is 0.1 , if it is compared with conventional learning.
\end{abstract}

Keywords: Self regulated learning, Realistic mathematics learning.

\section{PENDAHULUAN}

Saat ini, sebagian besar pembelajaran matematika yang dilakukan di SMP kurang mengembangkan kemandirian belajar siswa. Wolters, Pintrich, dan Karabenick (2003) menjelaskan bahwa kemandirian belajar sebagai suatu proses aktif dalam mengkonstruksi dan menetapkan tujuan belajar dan memonitor, mengatur, 
mengontrol kognisi, motivasi dalam konteks lingkungan. Pembelajaran yang dilakukan guru cenderung membuat siswa tidak mandiri. Karena siswa hanya memperhatikan penjelasan guru, mengikuti cara penyelesaian soal yang dicontohkan guru, dan menjalankan tugas yang diberikan guru.

Pembelajaran yang demikian, membuat siswa menjadi orang yang tergantung dengan orang lain, dalam hal ini guru. Siswa menjadi tidak berani menyampaikan ide-ide matematika yang dimilikinya. Akibatnya potensi matematika siswa tidak dapat berkembang secara optimum. Hal ini tampak dari hasil belajar matematika siswa yang rendah. Begitu pula, sikap siswa yang rendah terhadap matematika. Banyak siswa SMP di Kota Bengkulu yang tidak senang terhadap matematika.

Untuk meningkatkan kemandirian belajar matematika siswa, perlu dilakukan perbaikan pembelajaran, dari pembelajaran yang membatasi kemandirian belajar menjadi pembelajaran yang memberikan kesempatan seluas-luasnya bagi siswa untuk mandiri dalam memahami konsep-konsep matematika maupun dalam melakukan penyelesaian suatu masalah dalam matematika. Pembelajaran yang dapat mengakomodasi hal tersebut adalah pembelajaran matematika realistik.

Pembelajaran matematika realistik memberikan kesempatan yang seluas-luasnya kepada siswa untuk memahami suatu masalah, kemudian melakukan berbagai aktivitas untuk memecahkan masalah tersebut melalaui kegiatan doing mathematics seperti menyusun model masalah, berdiskusi, melakukan refleksi, dan akhirnya menemukan penyelesaian masalah dan menemukan berbagai konsep, prinsip, maupun algoritma dalam matematika. Menurut Haji (2015), realistic mathematics learning based on open-ended problem is mathematics learning that trigger students to solve an open-ended problem through discovery activities, reflection, and discussion. Pembelajaran matematika realistik memiliki 5 karakteristik, yakni (Traffers, 1987): 1. The use of context, 2. The use of models, 3. The use of students' own productions abd contructions, 4. The interactive character of teaching process, and 5. The intertwinement pf varios learning strands.

Beberapa hasil penelitian yang berkaitan dengan pembelajaran matematika realistik menunjukkan pembelajaran tersebut mampu membangun sikap yang postif terhadap matematika dan dapat meningkatkan hasil belajar matematika. Penelitian Chotijah dalam Suryanto (2010) menemukan bahwa pembelajaran matematika realistik dapat meningkatkan sikap positif siswa terhadap matematika. Begitu pula, hasil penelitian Aizah dalam Suryanto (2010) menemukan bahwa pembelajaran matematika realistik dapat meningkatkan kreativitas siswa dalam belajar matematika.

Rumusan masalah dalam penelitian ini sebagai berikut:

1. Apakah terdapat peningkatan kemandirian belajar siswa yang diajar melalui pembelajaran matematika realistik? 
2. Apakah pencapaian kemandirian belajar siswa yang diajar melalui pembelajaran matematika realistik lebih tinggi daripada yang diajar melalui pembelajaran konvensional?

Atas dasar rumusan masalah tersebut, maka tujuan penelitian ini untuk mengetahui:

1. Peningkatan kemandirian belajar siswa yang diajar melalui pembelajaran matematika realistik.

2. Pencapaian kemandirian belajar siswa yang diajar melalui pembelajaran matematika realistik.

\section{METODE PENELITIAN}

\section{Desain Penelitian}

Jenis penelitian ini adalah kuasi eksperimen dengan disain Nonrandomized control group, Pretest-Posttest Design), seperti yang dijelaskan Sugiyono (2006):

$\begin{array}{lll}\mathrm{Y}_{1} & \mathrm{X} & \mathrm{Y}_{2} \\ \mathrm{Y}_{1} & & \mathrm{Y}_{2}\end{array}$

Keterangan:

$\mathrm{Y}_{1}=$ pretest,

$\mathrm{Y}_{2}=$ posttest.

$\mathrm{X}=$ Perlakuan berupa pembelajaran matematika realistik.

\section{Tempat dan Waktu Penelitian}

Tempat Penelitian: SMPN 15 dan SMPN 3 Kota Bengkulu

Waktu Penelitian : Januari-Desember 2014

\section{Populasi dan Sampel}

Populasi penelitian ini adalah seluruh siswa Kelas VII SMPN 15 dan SMPN 3 Kota Bengkulu. Sedangkan sampel penelitian adalah seluruh siswa kelas VIIA SMPN 15 dan SMPN 3 Kota Bengkulu (Haji dan Abdullah,2014).

\section{Instrumen Penelitian dan Analisis Data}

Instrumen penelitian adalah angket kemandirian belajar siswa yang terdiri atas 42 pernyataan yang memuat pernyataan positif dan pernyataan negati tentang kemandirian belajar. Indikator kemandirian belajar terdiri dari: keyakinan motivasi, manajemen sumber daya, strategi metakognitif, dan strategi kognitif.

Langkah-langkah pengembangan angket kemandirian belajar sebagai berikut:

1. Menyusun kisi-kisi kemandirian belajar. 
2. Menyusun pernyataan-pernyataan tentang kemandirian belajar terdiri atas 42 pernyataan yakni 21 pernyataan positif dan 21 pernyataan negatif. Respon untuk setiap pernyataan terdiri atas lima klasifikasi yakni Sangat Tidak Setuju (STS), Tidak Setuju (TS), Ragu-Ragu (R), Setuju (S), dan Sangat Setuju (SS). Skor pernyataan positif sebagai berikut, $\mathrm{STS}=1$, $\mathrm{TS}=2, \mathrm{R}=3, \mathrm{~S}=4$, dan $\mathrm{SS}=5$. Sedangkan skor pernyataan negatif, $\mathrm{STS}=5, \mathrm{TS}=4, \mathrm{R}=3, \mathrm{~S}=2$, dan $\mathrm{SS}=1$.

3. Melakukan validasi (validasi isi dan validasi muka) terhadap angket kemandirian belajar. Validasi angket kemandirian belajar dilakukan oleh 4 orang dosen dan 2 orang guru matematika SMP.

4. Melakukan revisi angket kemandirian belajar.

5. Uji coba angket kemandirian belajar.

6. Menganalisis hasil uji coba angket kemandirian belajar.

Data penelitian ini dianalisis secara kuantitatif dan kualitatif. Analisis kuantitatif digunakan untuk mengetahui peningkatan dan pencapaian kemandirian belajar siswa setelah memperoleh pembelajaran matematika realistik. Sedangkan analisis kualitatif digunakan untuk mengetahui proses peningkatan dan pencapaian kemandirian belajar siswa.

\section{HASIL DAN PEMBAHASAN}

Berdasarkan hasil uji statistik peningkatan kemandirian belajar matematika siswa ditunjukkan pada tabel-tabel berikut ini.

Tabel 1. Hasil Uji Normalitas Data Awal, Akhir, dan N-gain Kemandirian Belajar Matematika Siswa

\begin{tabular}{|l|c|c|c|c|c|c|}
\hline \multicolumn{1}{|c|}{ Kelompok Data } & $N$ & $\begin{array}{c}\text { Rata- } \\
\text { rata }\end{array}$ & $\begin{array}{c}\text { Dev. } \\
\text { Stand. }\end{array}$ & $\begin{array}{c}\text { Kolmog } \\
\text { orov- } \\
\text { Smirnov } \\
Z\end{array}$ & $\begin{array}{c}\text { Sig. } \\
(2- \\
\text { arah })\end{array}$ & $\mathrm{H}_{0}$ \\
\hline Awal KBM Eksperimen & 27 & 163,93 & 24,82 & 1,038 & 0,232 & Diterima \\
\hline Awal KBM Kontrol & 24 & 168,54 & 16,06 & 0,797 & 0,549 & Diterima \\
\hline Akhir KBM Eksperimen & 27 & 176,85 & 14,03 & 0,621 & 0,835 & Diterima \\
\hline Akhir KBM Kontrol & 24 & 172,96 & 14,23 & 0,618 & 0,839 & Diterima \\
\hline N-gain KBM Eksperimen & 27 & 0,15 & 0,41 & 0,525 & 0,946 & Diterima \\
\hline N-gain KBM Kontrol & 24 & 0,05 & 0,35 & 0,655 & 0,784 & Diterima \\
\hline
\end{tabular}

Sumber: Haji dan Abdullah, 2014.

Hasil uji Kolmogorov-Smirnov menunjukkan semua data kemandirian belajar matematika siswa berdistribusi nomal, sehingga semua data perlu diuji homogenitas variansnya. 
Tabel 2. Hasil Uji Homogenitas Varians Data Awal, Akhir, dan N-gain Kemandirian Belajar Matematika Siswa

\begin{tabular}{|c|c|c|c|c|}
\hline Kelampok Data & $N$ & $F$ & Sig. (2-arah) & $\mathbf{H}_{0}$ \\
\hline Awal KBM Eksperimen & 27 & \multirow{2}{*}{0,442} & \multirow{2}{*}{0,509} & \multirow{2}{*}{ Diterima } \\
\hline Awal KBM Kontrol & 24 & & & \\
\hline Akhir KBM Eksperimen & 27 & \multirow{2}{*}{0,003} & \multirow{2}{*}{0,956} & \multirow{2}{*}{ Diterima } \\
\hline Akhir KBM Kontrol & 24 & & & \\
\hline N-gain KBM Eksperimen & 27 & \multirow{2}{*}{0,476} & \multirow{2}{*}{0,493} & \multirow{2}{*}{ Diterima } \\
\hline N-gain KBM Kontrol & 24 & & & \\
\hline
\end{tabular}

Sumber: Haji dan Abdullah, 2014.

Hasil uji Levene menunjukkan bahwa semua kelompok data memilki varians yang homogen. Oleh karena itu, uji perbedaan awal, pencapai, dan peningkatan KBM siswa antara kedua kelas meggunakan uji $-t$.

Tabel 3. Hasil Uji - $t$ Data Awal, Akhir, dan N-gain

Kemandirian Belajar Matematika Siswa

\begin{tabular}{|c|c|c|c|c|c|c|c|}
\hline $\begin{array}{c}\text { Kelompok } \\
\text { Data }\end{array}$ & $N$ & $\begin{array}{l}\text { Rata- } \\
\text { rata }\end{array}$ & $\begin{array}{c}\text { Beda } \\
\text { Rata- } \\
\text { rata }\end{array}$ & $t$ & $d f$ & $\begin{array}{c}\text { Sig. } \\
\text { (2-arah) }\end{array}$ & $\mathbf{H}_{0}$ \\
\hline $\begin{array}{l}\text { Awal KBM } \\
\text { Eksperimen }\end{array}$ & 27 & 163,93 & \multirow{2}{*}{4,61} & \multirow{2}{*}{$-0,777$} & \multirow{2}{*}{49} & \multirow{2}{*}{0,441} & \multirow{2}{*}{ Diterima } \\
\hline $\begin{array}{l}\text { Awal KBM } \\
\text { Kontrol }\end{array}$ & 24 & 168,54 & & & & & \\
\hline $\begin{array}{l}\text { Akhir KBM } \\
\text { Eksperimen }\end{array}$ & 27 & 176,85 & \multirow{2}{*}{3,89} & \multirow{2}{*}{0,982} & \multirow{2}{*}{49} & \multirow{2}{*}{0,331} & \multirow{2}{*}{ Diterima } \\
\hline $\begin{array}{l}\text { Akhir KBM } \\
\text { Kontrol }\end{array}$ & 24 & 172,96 & & & & & \\
\hline $\begin{array}{l}\mathrm{N} \text {-gain KBM } \\
\text { Eksperimen }\end{array}$ & 27 & 0,15 & \multirow{2}{*}{0,10} & \multirow{2}{*}{0,878} & \multirow{2}{*}{49} & \multirow{2}{*}{0,384} & \multirow{2}{*}{ Diterima } \\
\hline $\begin{array}{l}\mathrm{N}-\text { gain KBM } \\
\text { Kontrol }\end{array}$ & 24 & 0,05 & & & & & \\
\hline
\end{tabular}

Sumber: Haji dan Abdullah, 2014.

Hasil uji - $t$ menunjukkan bahwa tidak terdapat perbedaan yang signifikan kemandirian belajar matematika siswa antara kelas eksperimen dengan kelas kontrol, baik di awal pembelajaran, maupun pencapaian dan peningkatan kemandirian belajar matematika siswa.

Pencapaian kemandirian belajar matematik siswa yang diajar melalui pembelajaran matematika realistik sebesar 176,85 lebih besar daripada siswa yang diajar melalui pembelajaran konvensional (PK) sebesar 172,96.

Siswa yang diajar melalui pembelajaran matematika realistik lebih mandiri daripada siswa yang diajar melalui pembelajaran konvensional. Siswa lebih mandiri dalam memahami suatu permasalahan. Suatu masalah dapat dipahami dari berbagai sudut 
pandang. Seperti memahami persoalan bilangan negatif. Sebagian siswa memahami sebagai suatu 'hutang', sebagian siswa yang lain memahami sebagai suatu 'di bawah permukaan laut', dan ada juga yang memahami sebagai suatu 'panas badan', ada juga yang memahami sebagai suatu 'suhu dingin'.

Begitu pula dalam kemandirian merumuskan suatu model masalah. Siswa lebih mandiri dalam merumuskan model masalah tersebut. Sebagian siswa merumuskan suatu model masalah dengan menggunakan 'gambar', sebagian lain merumuskan dengan menggunakan 'tabel', dan sebagian yang lain merumuskan dengan menggunakan 'persamaan'.

Kemandirian dalam menggunakan cara menyelesaikan suatu masalahpun beragam. Sebagian siswa dalam menyelesaikan suatu masalah menggunakan 'cara singkat', sebagian lain menggunakan 'cara panjang', ada juga yang menggunakan cara 'gambar'.

Kemandirian dalam mendefinisikan suatu konsep matematikapun beragam. Seperti dalam menemukan konsep suatu segitiga. Sebagian siswa mendefinisikan segitiga sebagai suatu benda yang dibatasi oleh tiga buah sisi, ada juga yang mendefinisikan sebagai suatu daerah yang dibatasi oleh tiga buah garis, ada juga yang mendefinisikan segitiga sebagai suatu bangun yang terdiri atas perpotongan 3 buah garis.

Kemandirian siswa dalam belajar matematika tersebut terbentuk melalui aktivitas pembelajaran matematik realistik yaitu kegiatan memahami masalah kontekstual, menyusun model matematika, diskusi, interaktifitas, refleksi, dan invention (penemuan). Seperti dalam kegiatan memecahkan masalah jumlah penumpang bus sekolah yang memuat beberapa siswa dan terdapat silih berganti siswa yang turun dan naik bus serta berhenti di beberapa halte. Siswa memecahkan masalah tersebut dengan cara mempraktikan kegiatan menaiki dan menurun bus sekolah. Selama kegiatan tersebut, siswa dengan bebasnya berdiskusi dan berinteraksi dengan sesama siswa atau guru atau sumber belajar lainnya. Lalu mereka merumuskan model dan menyelesaikannya. Walaupun mereka berdiskusi dengan sesama temannya, namun dalam menyampaikan pendapat, merumuskan masalah atau cara menemukan penyelesaian, mereka lakukan dengan caranya sendiri.

Kemandirian belajar tersebut muncul, setelah mereka melakukan berulang kali menyelesaikan masalah dan ternyata mereka dapat menyelesaikannya dengan baik. Sehingga tumbuhlah kepercayaan diri mereka, bahwa ternyata mereka memiliki kemampuan dalam menyelesaikan masalah.

Selain itu dapat disimpulkan bahwa terdapat perbedaan yang signifikan peningkatan (N-gain) KKMM antara siswa kelas eksperimen dan siswa kelas kontrol. 
Peningkatan (N-gain) KKMM siswa kelas eksperimen sebesar 0,15 lebih tinggi dari siswa kelas kontrol sebesar 0,05.

Peningkatan kemandirian belajar siswa yang diajar melalui pembelajaran matematika realistik lebih baik daripada kemandirian belajar siswa yang diajar melalui pembelajaran konvensional. Karena pembelajaran matematika realistik memberikan kebebasan siswa melakukan aktivitas dalam memahami maupun memecahkan suatu masalah. Sementara itu, pembelajaran konvensional membatasi aktivitas siswa dalam memahami maupun menyelesaikan suatu masalah.

Dalam pembelajaran matematika realistik, siswa memahami suatu konsep matematika melalui aktivitas penyelesaian suatu masalah, sedangkan dalam pembelajaran konvensional, siswa memecahkan suatu masalah berdasarkan cara yang telah diajarkan oleh gurunya.

Pencapaian dan peningkatan kemandirian belajar matematika siswa yang diajar melalui pembelajaran matematika realistic dapat digambarkan sebagai berikut.

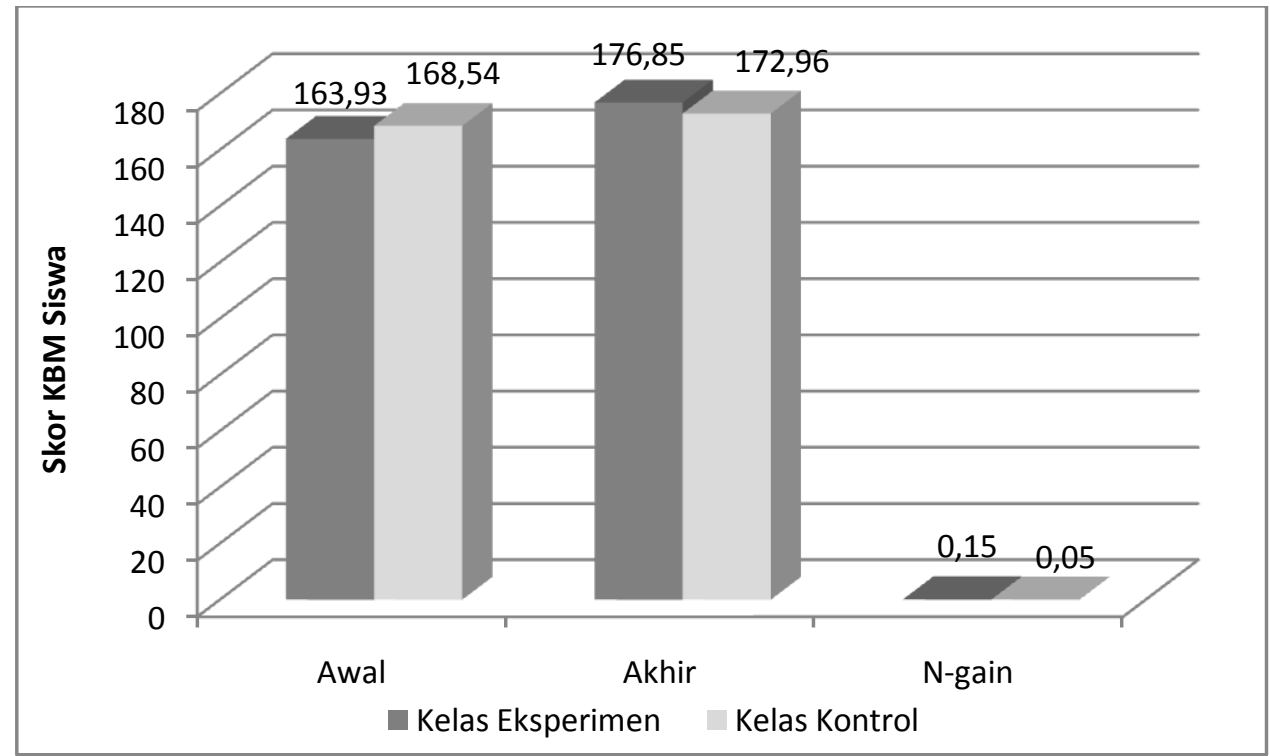

Sumber: Haji dan Abdullah, 2014.

Gambar 1. Skor Pencapaian dan Peningkatan Kemandirian Belajar Siswa 


\section{KESIMPULAN DAN SARAN}

\section{Kesimpulan}

a. Pencapaian kemandirian belajar siswa yang diajar melalui pembelajaran matematika realistik lebih tinggi daripada siswa yang diajar melalui pembelajaran konvensional. Pencapaian melalui pembelajaran matematika realistik sebesar 176,85 , sedangkan pencapaian melalui pembelajaran konvensional sebesar 172,96.

b. Terdapat peningkatan kemandirian belajar siswa yang diajar melalui pembelajaran matematika realistik sebesar 0,1 .

\section{Saran}

Untuk meningkatkan dan mencapai kemandirian belajar matematika siswa, hendaknya guru menerapkan pembelajaran matematika realistik. Siswa diberi kebebasan dalam memahami suatu masalah, merumuskan model masalah, menemukan cara menyelesaikan masalah, dan merumuskan hasil penyelesaian masalah maupun hasil temuannya.

\section{DAFTAR PUSTAKA}

Haji, S. (2015). Developing Students' Mathematical Reasoning Through Realistic Mathematics Learning Based On Open-Ended. Proceeding The 2015 International Seminar On Education, Organized by Faculty of Teacher Training and Education University of Bengkulu, Indonesia, 16-18 January 2015. ISBN: 978-602-8043-43-4.

Haji, S. dan Abdullah, M.I. (2014). Model Pembelajaran Matematika Realistik Untuk Meningkatkan Kemampuan Berpikir Matematika Tingkat Tinggi dan Kemandirian Belajar Siswa. Laporan Penelitian Tim Pascasarjana. Jakarta: Dikti. Tidak diterbitkan.

Sugiyono (2006). Metode Penelitian Pendidikan. Bandung: Alfabeta.

Suryanto (2010). Sejarah Pendidikan Matematika Realistik Indonesia (PMRI). Yogyakarta.

Traffers (1987). Three Dimentions, A Model of Goels in Theory Description in Mathematics Instruction. Dordrecht: Reidel Publishing Company.

Wolters, C.A. Pintrich, P.R. dan Karabeninch, S.A. (2003).Assesing Academis SelfRegulated Learning. National Institutes of Health March, Michigen. 